\title{
Chromosome pairing and germ cell loss in male and female mice carrying a reciprocal translocation
}

\author{
L. A. Setterfield, S. Mahadevaiah and U. Mittwoch \\ Department of Genetics and Biometry, University College London, Wolfson House, \\ 4 Stephenson Way, London NWI 2HE, U.K.
}

\begin{abstract}
Summary. Female carriers of the $\mathrm{T}(5 ; 12) 31 \mathrm{H}$ reciprocal translocation had an average reduction of $73 \%$ in oocyte numbers compared with normal litter mates, which was of a magnitude similar to the reduction in sperm counts of male carriers. Analysis of synaptonemal complexes showed that the translocated chromosomes appeared as quadrivalents, or trivalents and univalents, or bivalents in both sexes. Quadrivalents were of three types: fully synapsed, with asynapsis confined to breakpoints, and with unsynapsed ends. There was more pairing in spermatocytes than in oocytes: $37 \%$ of spermatocytes, but only $14 \%$ of oocytes, contained a fully synapsed quadrivalent, and trivalents were also more frequently fully synapsed in spermatocytes. When these results are compared with those previously obtained for other chromosome anomalies, it becomes evident that there are considerable differences in chromosome pairing between males and females, and that different chromosome rearrangements differ in the relative amount of pairing failure occurring in male and female carriers.
\end{abstract}

Keywords: Spermatogenic impairment; oogenic impairment; synaptonemal complex; reciprocal translocation; chromosomal asynapsis.

\section{Introduction}

Chromosome rearrangements can lead to breakdown of gametogenesis and infertility in mice and men. Although the underlying biological events linking cause and effect have not so far been completely elucidated, the opinion is widely held that the inability of full pairing between homologous chromosomes has a damaging effect on developing germ cells.

Since the discovery by Lyon \& Meredith (1966) that heterozygosity for certain reciprocal autosomal translocations in the mouse was associated with sterility in males, many other examples of such translocations have been reported (Searle, 1982). Sterility is due to impairment of spermatogenesis, the severity of which varies between different translocations, and sometimes also in the same translocation according to genetic background.

Male-sterile translocations typically have one breakpoint near the centromere, while the other chromosome is broken near the opposite, distal end, and this often gives rise to two marker chromosomes, one long and one short one. The latter, because of its small size, may be compatible with viability even if present in addition to the normal chromosome complement, and the majority of such tertiary trisomic mice are also male-sterile.

Although female translocation carriers and tertiary trisomics can reproduce, it is now known that oogenesis, too, is impaired. A reduction in ovary size in carriers of a reciprocal translocation (Mittwoch et al., 1981), and of two other autosomal anomalies (Mittwoch et al., 1984) suggested a reduction in the number of oocytes, and this was confirmed by oocyte counts (Burgoyne et al., 1985; Setterfield \& Mittwoch, 1986) in the reciprocal translocation $\mathbf{T}(11 ; 19) 42 \mathrm{H}$ and the tertiary trisomic $\operatorname{Ts}\left(5^{12}\right) 31 \mathrm{H}$ (these will subsequently be referred to as $\mathrm{T} 42 \mathrm{H}$ and $\mathrm{Ts} 31 \mathrm{H}$ respectively). Both 
anomalies are male-sterile, $\mathrm{T} 42 \mathrm{H}$ giving rise to azoospermia (all germ cells dying in pachytene) and Ts $31 \mathrm{H}$ to severe oligospermia, while average reductions in oocyte numbers amounted to $65 \%$ and $71 \%$ respectively. We now wish to describe a translocation in which the degree of gametogenic impairment in males and females is very similar.

The $\mathrm{T}(5 ; 12) 31 \mathrm{H}$ reciprocal translocation (henceforth referred to as $\mathrm{T} 31 \mathrm{H}$ ) was described by Beechey et al. (1980). One of the breakpoints is in chromosome 5, in band B, and the other is near the distal end of chromosome 12, in band F1. This gives rise to a short marker chromosome, $5^{12}$, and a long one, $12^{5}$. Beechey et al. (1980) found, on average, a $90 \%$ reduction in sperm count and a high frequency of abnormal spermatozoa, leading to sterility in most heterozygous male carriers. The degree of spermatogenic impairment was subject to considerable variation.

In an attempt to elucidate the impairment of gametogenesis in both sexes, we shall be giving a comparative account of chromosome pairing at the level of synaptonemal complexes in spermatocytes and oocytes. These results will be preceded by data on numbers of spermatozoa and oocytes in translocation carriers.

In view of the variation in the degree of spermatogenic breakdown observed by Beechey et al. (1980), we have obtained data on sperm counts and breeding ability in the males in which we examined chromosome pairing at meiotic prophase, and in a few others. Quantitative studies on oogenesis in $\mathrm{T} 31 \mathrm{H}$ translocation carriers have not previously been carried out and we therefore present data on oocyte numbers in 10 translocation carriers and their normal litter mates.

\section{Materials and Methods}

Mice. Female mice carrying the $\mathrm{T} 31 \mathrm{H}$ translocation were obtained from the MRC Radiobiology Unit, Chilton, and the stock was maintained by mating them to $\mathrm{C} 3 \mathrm{H}$ males. The presence or absence of the long and short marker chromosomes was assessed in post-natal animals from fibroblast cultures obtained from tail tips, and in fetuses to be used for pachytene analysis of oocytes from preparations of liver and spleen (Eicher \& Washburn, 1978).

Assessment of male fertility. Each male to be tested was put together with a female of proven fertility for up to 8 weeks. Subsequently the male was killed by cervical dislocation following ether anaesthesia, and both testes were weighed. Sperm counts were obtained from the heads of each epididymis, which were dissected out, minced in $1 \%$ trisodium citrate and, after diluting to $2 \mathrm{ml}$ and thorough mixing, were counted in a haemocytometer.

To assess motility, caudal spermatozoa were flushed out with warm culture medium, and examined under a microscope. The spermatozoa were checked to see whether a majority exhibited vigorous directional movement, markedly reduced movement, or none at all. These classes were given scores of 2,1 and 0 , respectively.

Ovarian volumes and oocyte counts were obtained from 8 litters aged 3-6 days containing $10 \mathrm{~T} 31 \mathrm{H} /+$ females and 10 chromosomally normal litter mates. The mice were killed by decapitation after anaesthesia, ovaries were dissected out, fixed in Bouin's fluid, sectioned at $7 \mu \mathrm{m}$, and stained with haematoxylin and eosin. Measurements were carried out using the distributed point counting method by Burgoyne \& Baker (1985; see also Setterfield \& Mittwoch, 1986). Essentially the method consists of sampling evenly distributed points over the entire section areas of the ovary while the sections themselves are not in focus by focussing on a squared grid attached to the bottom of the slide, while an eye piece graticule with central cross bar is also in focus. Subsequently, the section is examined under oil immersion, and it is recorded whether an oocyte or somatic cell was hit by the cross bar. The relative numbers of points in the two categories determine the proportion of germinal and somatic tissue in the ovary. Absolute values are obtained from area measurements of oocytes, with a correction made for the fact that large oocytes are more likely to be hit than small ones. For statistical analysis a weighted $t$ test was used, as described by Mittwoch et al. (1984).

Synaptonemal complexes. Spermatocytes were obtained from 4 heterozygous translocation carriers (Nos 360,424 , 432 and 436, see Table 1), and oocytes from 3 translocation-carrying fetuses (Nos 303E2, 422E2 and 422E3) aged 19 days (day of vaginal plug being counted as Day I). Gametocytes were prepared for analysis in the electron microscope using the method of Moses \& Poorman (1984) with minor modifications by Mahadevaiah \& Mittwoch (1986). Spermatocytes and oocytes were processed in identical ways. Silver staining was carried out by the method of Howell \& Black (1980).

Suitable fields of cells were selected in the light microscope under a $\times 12.5$ objective, and were cut with a Leitz diamond marker. The cut-out discs were floated onto water, and picked up on G100 grids for examination in a Philips 300 , or a Jeol 1200 , electron microscope at $80 \mathrm{kV}$. All complete pachytene cells were photographed and analysed. Incomplete cells, including those partly obscured by the grid, were excluded, as were all cells in meiotic stages other than pachytene. 


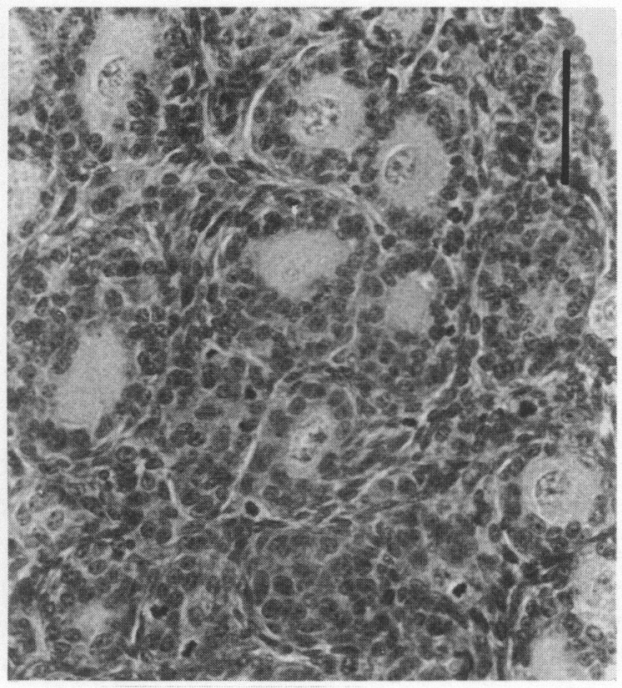

(a)

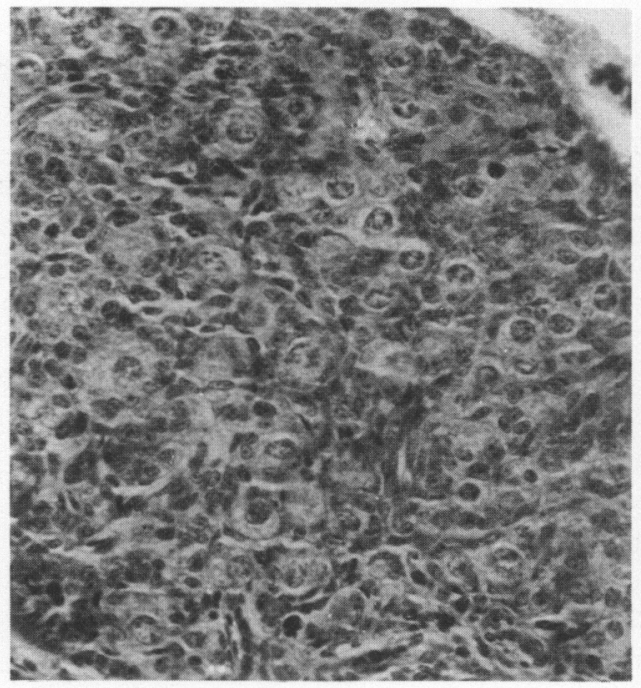

(b)

Fig. 1. Histological appearance of the ovary of (a) a 4-day-old T31H/+ mouse and (b) a 4-dayold normal mouse. Bar $=50 \mu \mathrm{m}$.

\section{Results}

\section{Gametogenic impairment}

Table 1 gives information on sperm output and male fertility. In spite of reduced testis weights and sperm counts, 6 out of 7 males were able to impregnate females. One male which failed to do so had totally immotile spermatozoa. A quantitative analysis of ovaries and their components is given in Table 2. It is evident that, although the two classes of mice did not differ in ovarian volume, the germinal volume was reduced in translocation carriers, and there was an even more marked reduction in oocyte numbers amounting to $74 \%$. By contrast, the mean oocyte size was larger in translocation carriers than in their normal sisters. This was because the small oocyte pool of translocation carriers was reduced by a relatively massive $80 \%$, whereas the number of growing oocytes was very slightly increased. The average number ( \pm standard error) of small oocytes in translocation carriers was $2438( \pm 363)$ compared with $11946( \pm 808)$ in normal litter mates, and that of large oocytes was $886( \pm 97)$ in translocation carriers, and $648( \pm 94)$ in normals. The difference in histology between the two types of ovary is illustrated in Fig. 1.

\section{Chromosome pairing in pachytene gametocytes}

The pair of translocated chromosomes and their normal homologues paired as a quadrivalent, or as a trivalent and univalent, or as bivalents, in spermatocytes and oocytes (Figs 2-4). However, the relative proportion of the different configurations varied in male and female gametocytes: whereas quadrivalents were the most common configuration seen in spermatocytes, trivalents, bivalents, and univalents were relatively more frequent in oocytes than in spermatocytes (Table 3 ). The proportion of doubtful configurations scored in oocytes was greater than that in spermatocytes because of the more frequent presence of synaptic errors and unpaired chromosomes in oocytes (see below).

For pairing between homologous chromosomes, quadrivalents formed between the translocated $5^{12}$ and $12^{5}$ and their nontranslocated homologues, 5 and 12 , could be fully synapsed or have 
Table 1. Fertility data of $\mathrm{T} 31 \mathrm{H} /+$ and chromosomally normal male mice

\begin{tabular}{|c|c|c|c|c|c|c|c|}
\hline Mouse no. & Chromosomes & $\begin{array}{c}\text { Mean testis } \\
\text { wt (mg) }\end{array}$ & $\begin{array}{l}\text { Mean caput } \\
\text { wt (mg) }\end{array}$ & $\begin{array}{l}\text { Sperm count } \\
\quad(\text { caput) } \\
\left(\times 10^{-6}\right)\end{array}$ & $\begin{array}{l}\text { Motility } \\
\text { score }\end{array}$ & $\begin{array}{c}\text { No. of } \\
\text { young } \\
\text { in test } \\
\text { litter }\end{array}$ & $\begin{array}{l}\text { Time until } \\
\text { birth of } \\
\text { litter } \\
\text { (days) }\end{array}$ \\
\hline Т31H 360 & $\mathrm{~T} 31 \mathrm{H} /+$ & $64 \cdot 5$ & $9 \cdot 8$ & 0.5 & 1 & 4 & 51 \\
\hline Т31H 368 & $\mathrm{~T} 31 \mathrm{H} /+$ & $74 \cdot 8$ & $12 \cdot 5$ & 0.51 & 1 & 1 & 43 \\
\hline Т31H 424 & $\mathrm{~T} 31 \mathrm{H} /+$ & $57 \cdot 4$ & $11 \cdot 7$ & 1.31 & 1 & 3 & 26 \\
\hline Т31H 432 & $\mathrm{~T} 31 \mathrm{H} /+$ & $64 \cdot 0$ & 6.9 & 0.7 & 1 & $0 \dagger$ & \\
\hline Т31H 436 & $\mathrm{~T} 31 \mathrm{H} /+$ & $54 \cdot 2$ & $12 \cdot 0$ & 1.86 & 1 & 4 & 35 \\
\hline Т31H 465 & T31H/ + & 59.8 & $12 \cdot 3$ & 0.83 & 1 & 3 & 27 \\
\hline T31H 392 & $\mathrm{~T} 31 \mathrm{H} /+$ & $59 \cdot 4$ & $12 \cdot 4$ & $0 \cdot 22$ & 0 & 0 & \\
\hline T31H 391* & $+1+$ & 105.9 & $17 \cdot 2$ & $2 \cdot 73$ & 2 & 5 & 28 \\
\hline C3H 365 & $+1+$ & 88.6 & $14 \cdot 2$ & $2 \cdot 47$ & 2 & 7 & 24 \\
\hline C $3 \mathrm{H} 366$ & $+1+$ & $87 \cdot 4$ & $14 \cdot 4$ & 2.53 & 2 & 2 & 40 \\
\hline
\end{tabular}

*Litter mate of T31H 392.

$\nmid$ Two embryos found 60 days after pairing.

Table 2. Quantitative analysis of ovarian components* in $\mathrm{T} 31 \mathrm{H} /+$ and normal littermate mice

\begin{tabular}{|c|c|c|c|c|c|c|c|c|}
\hline \multirow[b]{2}{*}{$\begin{array}{l}\text { Mouse } \\
\text { No. }\end{array}$} & \multirow[b]{2}{*}{$\begin{array}{c}\text { Age } \\
\text { (days) }\end{array}$} & \multirow[b]{2}{*}{$\begin{array}{l}\text { Chromo- } \\
\text { somes }\end{array}$} & \multirow{2}{*}{$\begin{array}{l}\text { Body } \\
\text { wt } \\
\text { (g) }\end{array}$} & \multirow{2}{*}{$\begin{array}{c}\text { Ovarian } \\
\text { vol. } \\
\left(\mathrm{mm}^{3}\right)\end{array}$} & \multicolumn{2}{|c|}{ Volume of tissue } & \multirow{2}{*}{$\begin{array}{c}\text { Mean } \\
\text { oocyte } \\
\text { vol. } \\
\left(\mathrm{mm}^{3} \times 10^{-6}\right)\end{array}$} & \multirow[b]{2}{*}{$\begin{array}{l}\text { No. of } \\
\text { oocytes }\end{array}$} \\
\hline & & & & & $\begin{array}{c}\text { Somatic } \\
\left(\mathrm{mm}^{3}\right)\end{array}$ & $\begin{array}{c}\text { Germinal } \\
\left(\mathrm{mm}^{3}\right)\end{array}$ & & \\
\hline $\begin{array}{l}56 \\
57\end{array}$ & 4 & $\begin{array}{c}+/+ \\
\mathrm{T} 31 \mathrm{H} /+\end{array}$ & $\begin{array}{l}4.96 \\
4.96\end{array}$ & $\begin{array}{l}0.066 \\
0.026\end{array}$ & $\begin{array}{l}0.045 \\
0.019\end{array}$ & $\begin{array}{l}0.021 \\
0.007\end{array}$ & $\begin{array}{l}i .456 \\
3.286\end{array}$ & $\begin{array}{r}14726 \\
2130\end{array}$ \\
\hline $\begin{array}{l}71 \\
72\end{array}$ & 4 & $\begin{array}{c}+/+ \\
\text { T31H/t+ }\end{array}$ & $\begin{array}{l}4.05 \\
3.77\end{array}$ & $\begin{array}{l}0.051 \\
0.045\end{array}$ & $\begin{array}{l}0.034 \\
0.030\end{array}$ & $\begin{array}{l}0.018 \\
0.014\end{array}$ & $\begin{array}{l}1 \cdot 771 \\
2 \cdot 981\end{array}$ & $\begin{array}{l}9883 \\
4843\end{array}$ \\
\hline $\begin{array}{l}222 \\
224 \\
223 \dagger\end{array}$ & 3 & $\begin{array}{c}+/+ \\
+/+ \\
\text { T31H/t }\end{array}$ & $\begin{array}{l}3.96 \\
3.54 \\
3 \cdot 52\end{array}$ & $\begin{array}{l}0.041 \\
0.048 \\
0.059\end{array}$ & $\begin{array}{l}0.026 \\
0.030 \\
0.039\end{array}$ & $\begin{array}{l}0.015 \\
0.018 \\
0.012\end{array}$ & $\begin{array}{l}1 \cdot 586 \\
1.388 \\
2.493\end{array}$ & $\begin{array}{r}9380 \\
12606 \\
4913\end{array}$ \\
\hline $\begin{array}{l}260 \\
259\end{array}$ & 5 & $\begin{array}{c}+/+ \\
\mathrm{T} 31 \mathrm{H} /+\end{array}$ & $\begin{array}{l}2.57 \\
3.35\end{array}$ & $\begin{array}{l}0.044 \\
0.046\end{array}$ & $\begin{array}{l}0.024 \\
0.034\end{array}$ & $\begin{array}{l}0.020 \\
0.011\end{array}$ & $\begin{array}{l}1.688 \\
6.266\end{array}$ & $\begin{array}{r}11925 \\
1815\end{array}$ \\
\hline $\begin{array}{l}275 \\
277 \\
276\end{array}$ & 4 & $\begin{array}{c}+1+ \\
+1+ \\
\text { T31H/+ }\end{array}$ & $\begin{array}{l}3.03 \\
3 \cdot 25 \\
3 \cdot 53\end{array}$ & $\begin{array}{l}0.035 \\
0.049 \\
0.042\end{array}$ & $\begin{array}{l}0.019 \\
0.028 \\
0.032\end{array}$ & $\begin{array}{l}0.016 \\
0.021 \\
0.009\end{array}$ & $\begin{array}{l}1.480 \\
1.493 \\
5.426\end{array}$ & $\begin{array}{r}10643 \\
14360 \\
1693\end{array}$ \\
\hline $\begin{array}{l}326 \\
325\end{array}$ & 5 & $\begin{array}{c}+/+ \\
\mathrm{T} 31 \mathrm{H} /+\end{array}$ & $\begin{array}{l}2 \cdot 32 \\
2 \cdot 57\end{array}$ & $\begin{array}{l}0.058 \\
0.048\end{array}$ & $\begin{array}{l}0.035 \\
0.035\end{array}$ & $\begin{array}{l}0.024 \\
0.014\end{array}$ & $\begin{array}{l}1 \cdot 652 \\
3 \cdot 121\end{array}$ & $\begin{array}{r}14298 \\
4346\end{array}$ \\
\hline $\begin{array}{l}338 \\
336 \\
337\end{array}$ & 4 & $\begin{array}{c}+/+ \\
\text { T31H/t } \\
\text { T31H/t }\end{array}$ & $\begin{array}{l}2 \cdot 12 \\
3 \cdot 51 \\
3 \cdot 44\end{array}$ & $\begin{array}{l}0.030 \\
0.042 \\
0.030\end{array}$ & $\begin{array}{l}0.017 \\
0.033 \\
0.023\end{array}$ & $\begin{array}{l}0.013 \\
0.009 \\
0.007\end{array}$ & $\begin{array}{l}1 \cdot 576 \\
3 \cdot 715 \\
3 \cdot 679\end{array}$ & $\begin{array}{l}8327 \\
2473 \\
2022\end{array}$ \\
\hline $\begin{array}{l}395 \\
393 \\
394\end{array}$ & 6 & $\begin{array}{c}+/+ \\
\mathrm{T} 31 \mathrm{H} /+ \\
\mathrm{T} 31 \mathrm{H} /+\end{array}$ & $\begin{array}{l}5.49 \\
5.07 \\
4.76\end{array}$ & $\begin{array}{l}0.080 \\
0.098 \\
0.090\end{array}$ & $\begin{array}{l}0.048 \\
0.080 \\
0.074\end{array}$ & $\begin{array}{l}0.032 \\
0.018 \\
0.016\end{array}$ & $\begin{array}{l}1.997 \\
4.830 \\
3.317\end{array}$ & $\begin{array}{r}15990 \\
3623 \\
4880\end{array}$ \\
\hline & $\begin{array}{l}\text { Normal } \mathrm{n} \\
\mathrm{T} 31 \mathrm{H} /+ \\
\text { Weighted } \\
\text { Standard } \\
\mathrm{t}_{7} \\
P\end{array}$ & & $\begin{array}{r}3.53 \\
3.85 \\
-0.22 \\
0.23 \\
-0.93 \\
\text { N.S. }\end{array}$ & $\begin{array}{c}0.050 \\
0.052 \\
1 \cdot 12 \times 10^{-3} \\
6.04 \times 10^{-3} \\
0.186 \\
\text { N.S. }\end{array}$ & $\begin{array}{c}0.031 \\
0.040 \\
-6.39 \times 10^{-3} \\
5.49 \times 10^{-3} \\
-1.17 \\
\text { N.S. }\end{array}$ & $\begin{array}{c}0.020 \\
0.012 \\
8.65 \times 10^{-3} \\
1.62 \times 10^{-3} \\
5.34 \\
<0.01\end{array}$ & $\begin{array}{c}1.609 \\
3.912 \\
-2.28 \\
0.45 \\
-5.07 \\
<0.01\end{array}$ & $\begin{array}{r}12214 \\
3274 \\
8997 \\
1019 \\
8.83 \\
<0.001\end{array}$ \\
\hline
\end{tabular}

*Left ovaries were measured throughout except for Mice 56, 57, 259 and 260 for which right ovaries were used.

$\dagger$ This ovary contained heteropycnotic cells which were not counted as somatic or germinal cells but which are included in the total ovarian volume estimates. 
Table 3. Types of translocation configurations in pachytene of spermatocytes and oocytes of $\mathrm{T} 31 \mathrm{H} /+$ mice

\begin{tabular}{|c|c|c|c|c|c|c|}
\hline & \multirow[b]{2}{*}{$\begin{array}{l}\text { No. of mice } \\
\text { or embryos }\end{array}$} & \multicolumn{4}{|c|}{ Mean no. of cells with } & \multirow[b]{2}{*}{ Total } \\
\hline & & Quadrivalents & $\begin{array}{c}\text { Trivalents } \\
+ \\
\text { univalents }\end{array}$ & $\begin{array}{c}2 \text { Bivalents, } \\
1 \text { bivalent }+ \\
2 \text { univalents, } \\
\text { or } \\
4 \text { univalents }\end{array}$ & $\begin{array}{c}\text { Doubtful } \\
\text { configurations }\end{array}$ & \\
\hline Spermatocytes & 4 & $102(0 \cdot 75)$ & $25(0 \cdot 18)$ & $3(0 \cdot 02)$ & $6(0 \cdot 04)$ & 136 \\
\hline Oocytes & 3 & $38(0 \cdot 36)$ & $40(0 \cdot 37)$ & $12(0 \cdot 11)$ & $17(0 \cdot 16)$ & 107 \\
\hline
\end{tabular}

asynapsed regions confined to the breakpoints, or have unsynapsed ends (Figs 2a \& 2c). Trivalents were fully synapsed or had asynapsed ends (Figs $2 d \& 3 a$ ); however, gametocytes containing a trivalent also included a small univalent chromosome, $5^{12}$ (Figs $2 \mathrm{~d}, 3 \mathrm{a} \& 3 \mathrm{c}$ ). It is evident from Fig. 5 that full synapsis of quadrivalents and trivalents was more likely to be achieved in spermatocytes than in oocytes. This fact, added to the different distribution of translocation configurations in male and female gametocytes, resulted in $37 \%$ of the spermatocytes having fully synapsed chromosomes, compared with $14 \%$ of oocytes; an additional third of oocytes contained trivalents with asynapsed ends. Table 4 shows that in spermatocytes association of the translocated chromosomes with the XY bivalent occurred most frequently in trivalent plus univalent configurations (Fig. 2d), and least often in quadrivalents with synapsed ends.

Errors of pairing could also occur in chromosomes that were not involved in the translocation, and the results in Table 5 show that oocytes were more prone to such errors than were spermatocytes. If univalent $\mathrm{X}$ and $\mathrm{Y}$ chromosomes were excluded, there were only 5 spermatocytes $(4 \%)$ with autosomal pairing errors. The corresponding figure for oocytes must be many times greater, for although the proportion of synaptic errors involving the $\mathrm{X}$ chromosomes is unknown, there was no reason to believe that the two $\mathrm{X}$ chromosomes in oocytes were more liable to such errors than were autosomes.

A significant proportion of unsynapsed or partly synapsed bivalents in oocytes was closely associated with the translocation configuration (Fig. 3c). The rather large number of cells in which such an association remained uncertain was due to the fact that oocytes not infrequently contained a great many synaptic errors within the same cell.

\section{Discussion}

The fact that 6 out of 7 males were successful in impregnating females, whereas Beechey et al. (1980) found that 19 out of $24 \mathrm{~T} 31 \mathrm{H}$-carrying males were sterile, suggests that the reproductive performance of these males might have improved somewhat since they were first described, although different criteria of assessing fertility need to be taken into account. An improvement in the level of spermatogenesis achieved by the males in our data is also suggested by the fact that the average testis weight was $62 \mathrm{mg}$, compared with $55.4 \mathrm{mg}$ reported by Beechey et al. (1980). Nevertheless, all the males tested by us had reduced (compared with $\mathrm{C} 3 \mathrm{H}$ normal mice) weights of testes and of epididymides, sperm counts, and sperm motilities, indicating spermatogenic impairment and possible subfertility. Litter size cannot be directly compared with that of chromosomally normal males, since the translocation would be expected to give rise to a proportion of chromosomally unbalanced spermotozoa and inviable conceptuses. This is known to occur in females (Beechey et al., 1980), but there are no data as yet for males. 


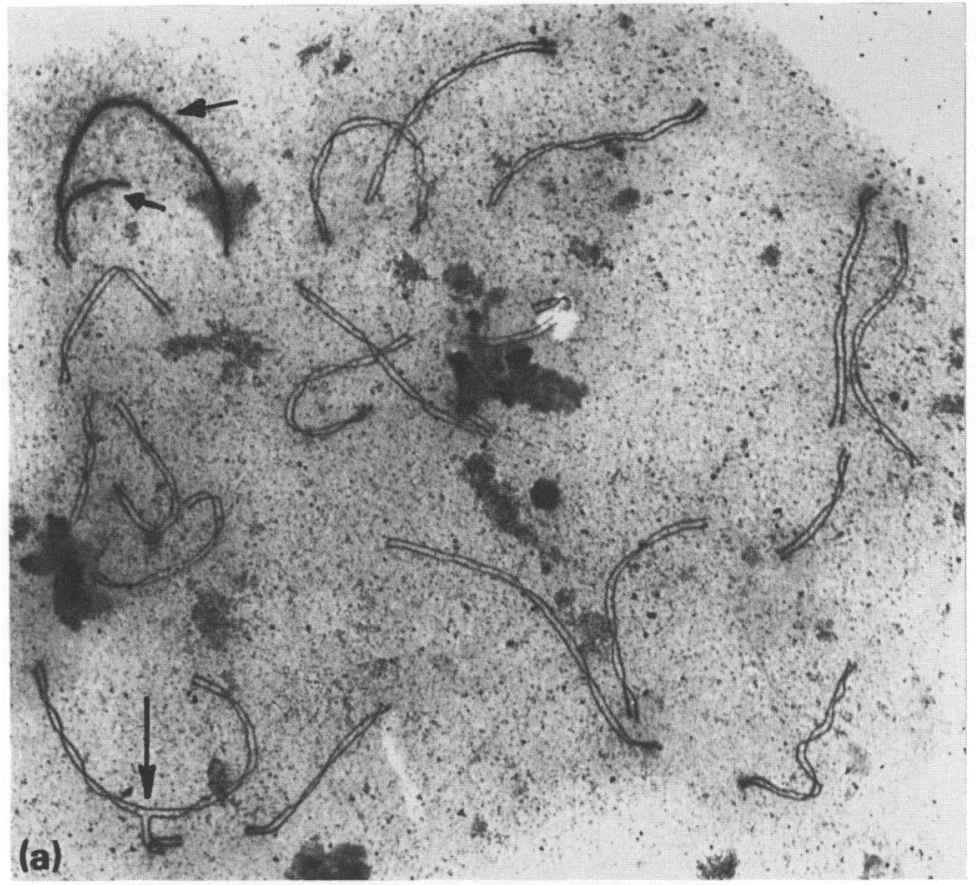

(a)

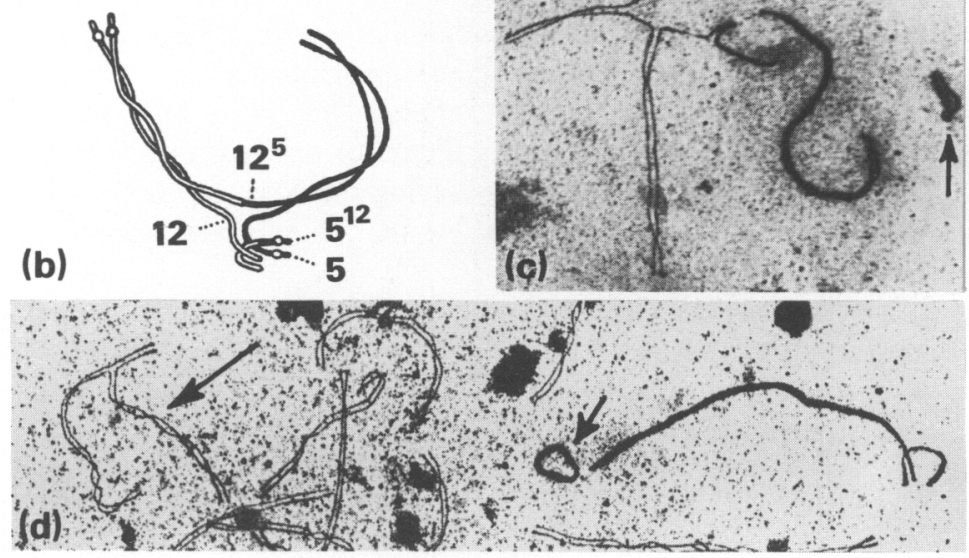

Fig. 2. Synaptonemal complexes of translocation configurations in $\mathrm{T} 31 \mathrm{H} /+$ spermatocytes. (a) Complete cell containing a fully paired quadrivalent. No association between quadrivalent (long arrow) and XY bivalent (short arrow). $\times 4000$. (b) Diagram of configuration in (a). (c) Terminally asynapsed quadrivalent associated with univalent $X$ chromosome. Univalent $\mathrm{Y}$ (arrow) folded back. $\times 4000$. (d) Fully synapsed trivalent (long arrow) plus ring-shaped univalent (short arrow) associated with XY. $\times 3400$.

The average reduction in sperm count of $\mathrm{T} 31 \mathrm{H}$-carrying males was about $70 \%$, while the reduction in oocyte numbers of translocation-carrying females was $74 \%$, a figure similar to that obtained for tertiary trisomic females, $\mathrm{Ts} 31 \mathrm{H}$, which carry the $5^{12}$ marker chromosome in addition to an otherwise normal diploid karyotype, and for females carrying the reciprocal translocation, $\mathrm{T} 42 \mathrm{H}$ (Burgoyne et al., 1985; Setterfield \& Mittwoch, 1986). However, this translocation causes complete breakdown of spermatogenesis during pachytene, leading to azoospermia, whereas tertiary trisomic 

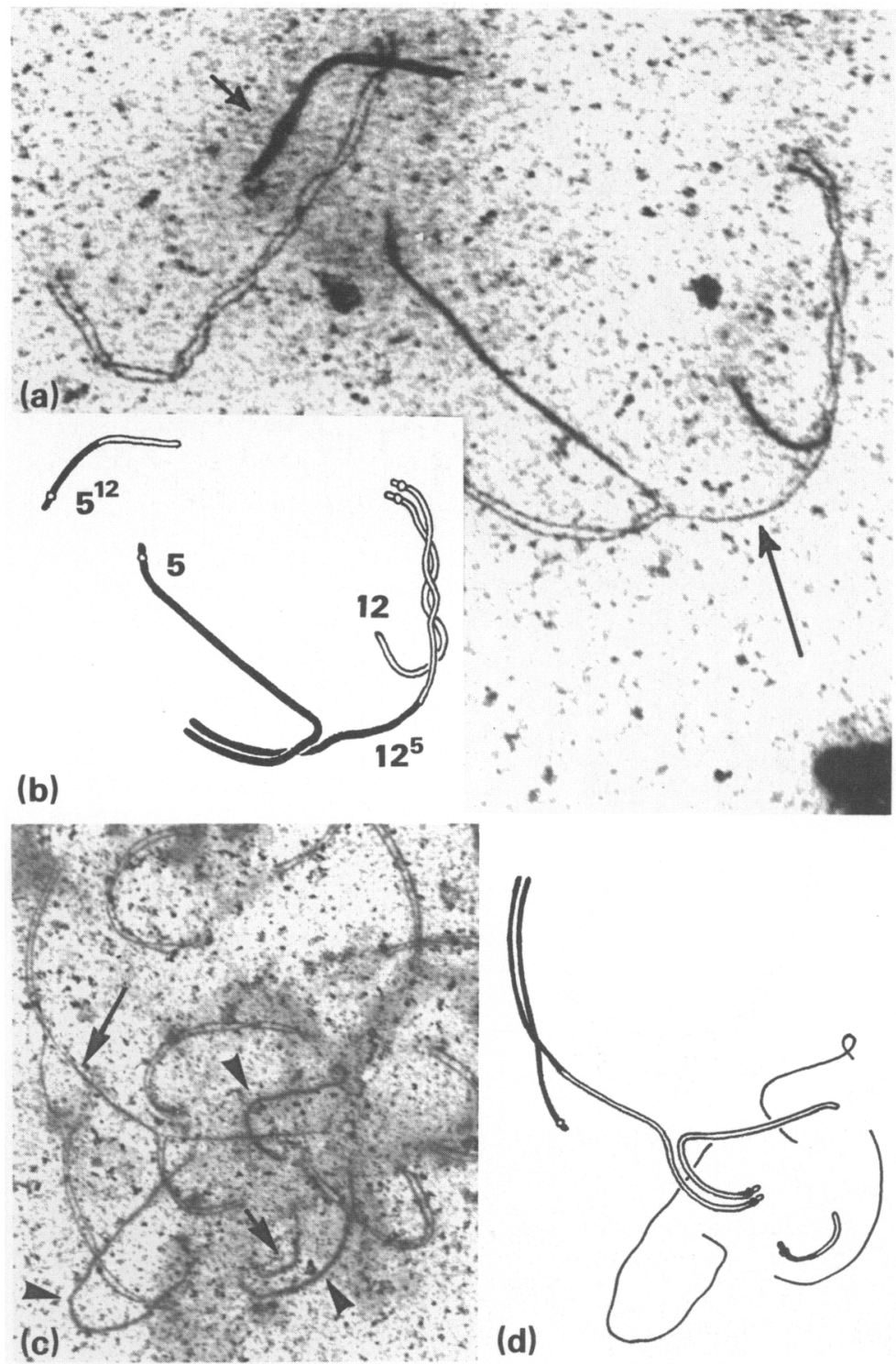

Fig. 3. Translocation configurations in $\mathrm{T} 31 \mathrm{H} /+$ oocytes. (a) Terminally asynapsed trivalent (long arrow) + univalent (short arrow) $\times 7800$. (b) Diagram of trivalent in (a). (c) Terminally asynapsed trivalent (long arrow) + univalent (short arrow). Trivalent is associated with univalent chromosomes (arrowheads) not involved in the translocation. $\times 4000$. (d) Diagram of trivalent in $(\mathrm{c})$.

males have very severe oligospermia. The fact that in $\mathrm{T} 31 \mathrm{H}$ mice breakdown of gametogenesis is of similar order of magnitude in both sexes makes a comparison of chromosome pairing of particular interest.

One of the striking results emerging from our data is that the degree of pairing achieved by spermatocytes was markedly higher than that in oocytes. Although the range of translocation configurations was the same in male and female germ cells, quadrivalents with fully paired ends were more than twice as common in spermatocytes than in oocytes (Table 3). In oocytes, most 


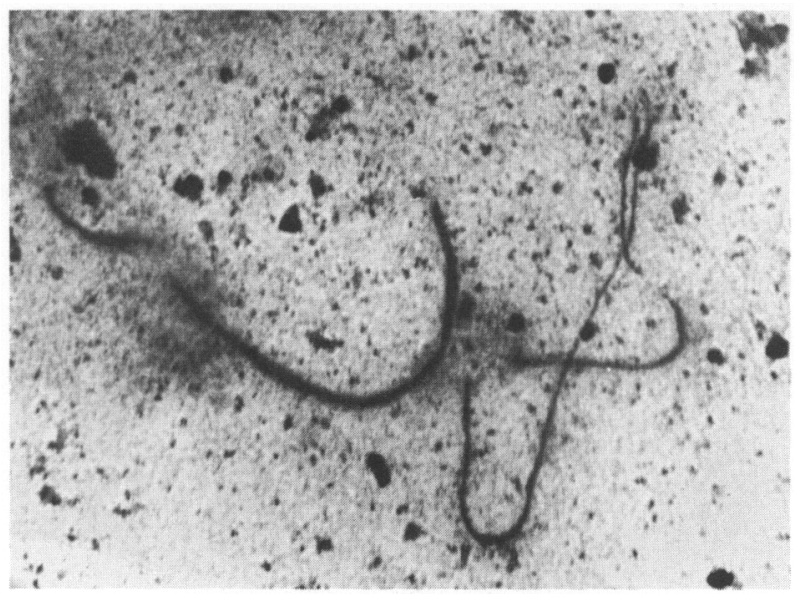

Fig. 4. A bivalent and two univalents in a $\mathrm{T} 31 \mathrm{H} /+$ oocyte. $\times 6300$.

Table 4. Position of different types of translocation configurations in relation to the $\mathrm{XY}$ bivalent

\begin{tabular}{lccc}
\hline & \multicolumn{2}{c}{$\begin{array}{c}\text { No. of cells in which translocation } \\
\text { configuration and XY are }\end{array}$} & \\
\cline { 2 - 3 } $\begin{array}{l}\text { Type of } \\
\text { configuration }\end{array}$ & Associated & Not associated & Total \\
\hline $\begin{array}{l}\text { Quadrivalents with } \\
\text { synapsed ends }\end{array}$ & $26(0.39)$ & $40(0.61)$ & 66 \\
$\begin{array}{l}\text { Quadrivalents with } \\
\text { asynapsed ends }\end{array}$ & $23(0.63)$ & $13(0.36)$ & 36 \\
$\begin{array}{l}\text { Trivalents + univalents } \\
\text { Total }\end{array}$ & $23(0.92)$ & $2(0.08)$ & 25 \\
\hline & $72(0.57)$ & $55(0.43)$ & 127 \\
\hline
\end{tabular}

Table 5. Synaptic errors in chromosomes other than 5 and 12 and their position in the cell in relation to translocation configurations

\begin{tabular}{|c|c|c|c|c|c|}
\hline & \multicolumn{4}{|c|}{ No. of cells with synaptic errors* } & \multirow[b]{2}{*}{$\begin{array}{l}\text { Total no } \\
\text { of cells } \\
\text { analysed }\end{array}$} \\
\hline & Total & $\begin{array}{l}\text { Associated with } \\
\text { translocation } \\
\text { configuration }\end{array}$ & $\begin{array}{l}\text { Not associated with } \\
\text { translocation } \\
\text { configuration }\end{array}$ & $\begin{array}{l}\text { Association } \\
\text { not known }\end{array}$ & \\
\hline Spermatocytes & $19 \dagger$ & 1 & $18 \dagger$ & 0 & 136 \\
\hline Oocytes & 31 & 8 & 11 & 12 & 107 \\
\hline
\end{tabular}

*Includes pairing failure and non-homologous pairing.

tOf these cells, 16 contained $\mathrm{X}, \mathrm{Y}$ univalents and 5 cells contained autosomal errors. 


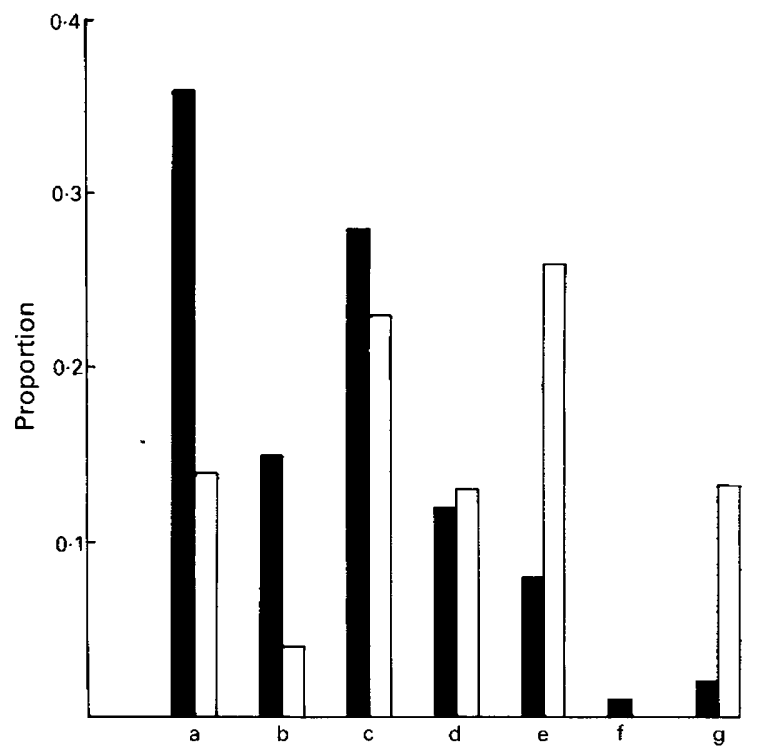

Fig. 5. Proportion of translocation configurations seen in spermatocytes (solid bars) and oocytes (open bars): (a) fully synapsed quadrivalents; (b) quadrivalents with synapsed ends but asynapsed around breakpoints; (c) quadrivalents with asynapsed ends; (d) fully synapsed trivalent + univalent; (e) trivalent with asynapsed end + univalent; (f) 2 bivalents, fully synapsed; (g) bivalents and/or univalents (asynapsed).

quadrivalents and trivalents were unsynapsed. Our data relating to the proximity of translocation configurations to the XY bivalent confirm the finding by de Boer et al. (1986) that configurations with synapsed ends are least likely to be associated with the XY bivalent, and that univalents are most likely to show such an association (Table 5). De Boer et al. (1986) also found a similar relationship with breakdown of spermatogenesis.

It is widely believed today that spermatogenic breakdown in carriers of reciprocal chromosomal translocations is a consequence of pairing failure at meiosis (Searle, 1982). Miklos (1974) proposed that saturation of pairing sites between homologous chromosomes is a prerequisite for meiotic and post-meiotic development of male germ cells, so that any pairing difficulty would be expected to lead to spermatogenic breakdown, whereas Forejt (1984) postulated that the adverse effect on spermatogenesis is not a direct effect of unpaired chromosomes but results from the association of unpaired autosomes with the $\mathrm{X}$ chromosome and consequent interference with its inactivation in primary spermatocytes. When it became apparent that oogenesis, too, is affected in karyotypes with an inability of chromosomes to pair during meiosis, Burgoyne \& Baker (1984) extended the hypothesis by Miklos (1974) to apply also to female germ cells, although interference with X chromosome inactivation could cause additional damage to male germ cells (Burgoyne et al., 1985).

We previously showed that in trisomic Ts $31 \mathrm{H}$ mice, in which the amount of unpaired chromosomal material originating from the translocation configuration is similar in males and females, being confined to the small marker chromosome, the number of oocytes was reduced by about $70 \%$ (Setterfield \& Mittwoch, 1986), which compares with sperm counts of barely $1 \%$ of normal (Beechey et al., 1980). In conjunction with the data on $\mathrm{T} 31 \mathrm{H}$, this might suggest that the same amount of unpaired chromosomal material is associated with more severe breakdown of spermatogenesis than of oogenesis, whereas similar degrees of gametogenic breakdown in males and females are associated with additional asynapsis in females. This supposition is supported by results on the insertion, Is $(7 ; 1) 40 \mathrm{H}$, in which there is complete spermatogenic breakdown during early pachytene. Oocyte numbers were reduced by only $55 \%$ (S. Parry, L. A. Setterfield \& U. Mittwoch, unpublished data), 
and terminal asynapsis was observed more frequently in males than in females (S. Mahadevaiah, unpublished data).

Chandley et al. (1986) have described a reciprocal translocation in an infertile man, whose sperm count was reduced by $90 \%$, and in whom only $20 \%$ of pachytene configurations were associated with the XY bivalent. Although the large majority of translocation configurations showed pairing failures, terminal asynapsis was present in only a minority of cells, which could account for the low level of XY association. While there is good evidence that terminal asynapsis in an autosomal configuration increases the chance of association with the $\mathrm{XY}$ bivalent, the effect of this association on spermatogenesis remains uncertain. The patient described by Chandley et al.(1986) had inherited the translocation from his mother but nothing seems to be known for man about the effect of male-sterile translocations on oogenesis in female carriers.

While there is now abundant evidence of an association between failure of chromosome pairing in meiosis and germ cell death, the exact relationship between cause and effect is not always apparent. There have been a number of reports on germ cell impairment before meiosis, particularly in human trisomy syndromes. For instance, Mikamo et al. (1968) found germ cell numbers in three infants with Klinefelter's syndrome to be below normal, and Coerdt et al. (1985) reported germ cell numbers to be reduced in fetuses with trisomy syndromes 13,18 and 21 , as well as XXY. In the patient with a 9;20 reciprocal translocation described by Chandley et al. (1986), the authors detected germ cell degeneration from early prophase onwards, while Speed (1986) concluded that the atresia seen in human XO fetuses originates mainly in very early meiosis before the start of pairing. On the other hand, testicular volumes, protein and DNA contents of $\mathrm{T} 42 \mathrm{H} /+$ mice were indistinguishable from normal during the first post-natal week (Mittwoch, 1982), and similar results were obtained for Is $40 \mathrm{H} /+$ and Ts $31 \mathrm{H}$ males (L. A. Setterfield, unpublished data), suggesting that large-scale losses of germ cells do not occur long before the onset of meiosis in these male-sterile stocks.

Irrespective of whether germ cell death is initiated before zygotene of meiosis, our data on mice show that pairing failure is not merely a function of the structure and contents of the chromosomes involved, but that the degree of synapsis can differ between spermatocytes and oocytes. What is perhaps more surprising is that different rearrangements differ as to whether male or female germ cells exhibit the greater degree of asynapsis and so there appears to be no simple relationship between the degree of gametogenic impairment in males and females.

The data in Table 2 show that there was no reduction in the somatic component of the ovaries of $\mathrm{T} 31 \mathrm{H}$-carrying females. In $\mathrm{Ts} 31 \mathrm{H}$ females, somatic ovarian tissue was reduced, although the difference was less than that of germinal tissue (Setterfield \& Mittwoch, 1986), while in T42H females a reduction in somatic tissue did not reach statistical significance (Burgoyne et al., 1985). The most likely conclusion is that pairing failure at meiosis in females is connected with impairment of oogenesis, and that any reduction in the somatic tissue of the ovary is a secondary effect.

Impairment of oogenesis is not expected to affect ovulation rates, since these are not dependent on the oocyte pool (Burgoyne \& Baker, 1984). Normal ovulation rates in the presence of reduced oocyte numbers are undoubtedly an important reason for the earlier assumption that male-sterile chromosome anomalies have no effect on oogenesis. A smaller than normal oocyte pool would, however, be expected to result in a reduction in reproductive life span, and Searle et al. (1983) reported evidence for this in female carriers of the Is $40 \mathrm{H}$ insertion.

The rather large number of synaptic errors in oocytes of chromosomes not involved in the translocation is in agreement with findings for $\mathrm{Ts} 31 \mathrm{H}$ and chromosomally normal female mice (Mahadevaiah \& Mittwoch, 1986), as well as in human oocytes (Speed, 1985). The high proportion of pairing anomalies seen in chromosomally normal oocytes, but not in spermatocytes, is likely to reflect the wave of degeneration that occurs during female meiosis (Weir \& Rowlands, 1977), and is probably the result, rather than the cause, of oocytes that are moribund. Nevertheless, the proportion of such cells may be increased in the presence of a systemic chromosomal error, as was found by Speed (1986) in XO fetuses of humans and mice. 
Our results show that oocytes that would normally be destined to proceed through oogenesis react to pairing difficulties due to chromosome rearrangements by synaptic failure, the amount of which may be higher or lower than that exhibited by spermatocytes. For mice with the $\mathrm{T} 31 \mathrm{H}$ translocation it is higher, and is associated with oogenic impairment which is of a magnitude similar to the spermatogenic impairment seen in male carriers.

We thank Dr Giorgio Gabella and Professor G. B. Isaacson for use of their electron microscopes; Stephen Hunt, Graham McPhail and Carole Marley for expert technical assistance; A. J. Lee for the graphical work; and the Wellcome Trust, The Rockefeller Foundation and the AFRC for financial support.

\section{References}

Beechey, C.V., Kirk, M. \& Searle, A.G. (1980) A reciprocal translocation induced in an oocyte and affecting fertility in male mice. Cytogenet. Cell Genet. 27, $129-146$.

Burgoyne, P.S. \& Baker, T.G. (1984) Meiotic pairing and gametogenic failure. In Controlling Events in Meiosis, pp. $349-362$. Eds C. W. Evans \& H. G. Dickinson. Company of Biologists, Cambridge.

Burgoyne, P.S. \& Baker, T.G. (1985) Perinatal oocyte loss in XO mice and its implication for the aetiology of gonadal dysgenesis in XO women. J. Reprod. Fert. 75, 633-645.

Burgoyne, P.S., Mahadevaiah, S. \& Mittwoch, U. (1985) A reciprocal autosomal translocation which causes male sterility in the mouse also impairs oogenesis. $J$. Reprod. Fert. 75, 647-652.

Chandley, A.C., Speed, R.M., McBeath, S. \& Hargreave, T.B. (1986) A human 9;20 reciprocal translocation associated with male infertility analysed at prophase and metaphase I of meiosis. Cytogenet. Cell Genet. 41, 145-153.

Coerdt, W., Rehder, H., Gausmann, I., Johannisson, R. \& Gropp, A. (1985) Quantitative histology of human fetal testes in chromosomal disease. Pediat. Pathol. 3, 245-259.

de Boer, P., Searle, A.G., Van der Hoeven, F.A., de Rooij, D.G. \& Beechey, C.V. (1986) Male pachytene pairing in single and double translocation heterozygotes and spermatogenic impairment in the mouse. Chromosoma 93, 326-336.

Eicher, E.M. \& Washburn, L.L. (1978) Assignment of genes to regions of mouse chromosomes. Proc. natn. Acad. Sci. U.S.A. 75, 946-950.

Forejt, J. (1984) X-inactivation and its role in male sterility. In Chromosomes Today, vol. 8, pp. 117-127. Eds M. D. Bennett, A. Gropp \& U. Wolf. Allen \& Unwin, London.

Howell, W.M. \& Black, D.A. (1980) Controlled silverstaining of nucleolus organizer regions with a protective colloidal developer: a 1-step method. Experientia 36, 1014-1015.

Lyon, M.F. \& Meredith, R. (1966) Autosomal translocations causing male sterility and viable aneuploidy in the mouse. Cytogenetics 5, 335-354.

Mahadevaiah, S. \& Mittwoch, U. (1986) Synaptonemal complex analysis in spermatocytes and oocytes of tertiary trisomic $\mathrm{Ts}\left(5^{12}\right) 31 \mathrm{H}$ mice with male sterility. Cytogenet. Cell Genet. 41, 169-176.
Mikamo, K., Aguercif, M., Hazeghi, P., Martin-Du Pan, R. (1968) Chromatin-positive Klinefelter's syndrome. A quantitative analysis of spermatogonial deficiency at 3, 4 and 12 months of age. Fert. Steril. 19, 731-739.

Miklos, G.L.G. (1974) Sex-chromosome pairing and male fertility. Cytogenet. Cell Genet. 13, 558-574.

Mittwoch, U. (1982) The difficulties of becoming a father. In Genetic Control of Gamete Production and Function, pp. 21-31. Eds P. G. Crosignani, B. L. Rubin \& M. Fraccaro. Academic Press, London.

Mittwoch, U., Mahadevaiah, S. \& Olive, M.B. (1981) Retardation of ovarian growth in male-sterile mice carrying an autosomal translocation. J. med. Genet. 18, 414-417.

Mittwoch, U., Mahadevaiah, S. \& Setterfield, L.A. (1984) Chromosomal anomalies that cause male sterility in the mouse also reduce ovary size. Genet. Res. 44, 219-224.

Moses, M.J. \& Poorman, P.A. (1984) Synapsis, synaptic adjustment and DNA synthesis in the mouse. In Chromosomes Today, vol. 8, pp. 80-103. Eds M. D. Bennett, A. Gropp \& U. Wolf. Allen \& Unwin, London.

Searle, A.G. (1982) The genetics of sterility in the mouse. In Genetic Control of Gamete Production and Function, pp. 93-114. Eds P. G. Crosignani, B. L. Rubin \& M. Fraccaro. Academic Press, London.

Searle, A.G., Beechey, C.V., de Boer, P., de Rooij, D.J., Evans, E.P. \& Kirk, M. (1983) A male-sterile insertion in the mouse. Cytogenet. Cell Genet. 36, 617-626.

Setterfield, L.A. \& Mittwoch, U. (1986) Reduced oocyte numbers in tertiary trisomic mice with male sterility. Cytogenet Cell Genet. 41, 177-180.

Speed, R.M. (1985) The prophase stages in human foetal oocytes studied by light and electron microscope. Hum. Genet. 69, 69-75.

Speed, R.M. (1986) Oocyte development in XO foetuses of man and mouse: the possible role of heterologous $\mathrm{X}$-chromosome pairing in germ cell survival. Chromosoma 94, 115-124.

Weir, B.J. \& Rowlands, I.W. (1977) Ovulation and atresia. In The Ovary, 2nd edn, Vol. 1. General Aspects, pp. 265-301. Eds S. Zuckerman \& B. J. Weir. Academic Press, New York. 